\title{
Türkçe Dersi Öğretim Programı “Öğrenmeyi Öğrenme” Yetkinlik Alanının Öğretmen Görüşlerine Göre Değerlendirilmesi
}

\section{Evaluating the Curriculum of Turkish Language Lesson in Terms of the Competency Area "Learning to Learn" According to Teachers' Views}

\author{
Ali Kocayiğit a , Çiğdem Aldan Karademir b,* \\ a Öğretmen, Milli Eğitim Bakanlığı, 15100, Burdur/Türkiye \\ ORCID: 0000-0003-0110-9422

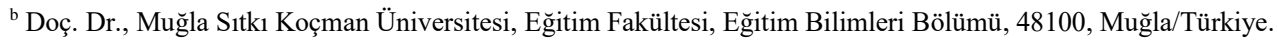 \\ ORCID: 0000-0001-9431-9992
}

\section{MAKALE BİLGISİ}

\section{Makale Geçmişi:}

Başvuru tarihi: 31 Ekim 2019

Düzeltme tarihi: 20 Mart 2020

Kabul tarihi: 09 Nisan 2020

\section{Anahtar Kelimeler: \\ Türkçe Dersi \\ Öğretim Programı \\ Yetkinlikler \\ Öğrenmeyi Öğrenme \\ Öğretmen Görüşleri}

\section{ARTICLE INFO}

\section{Article history:}

Received 31 October 2019

Received in revised form 20 March 2020 Accepted 09 April 2020

\section{Keywords:}

Turkish Language Lesson

Curriculum

Competencies

Learning to Learn

Teachers' Views

\section{ÖZ}

Bu araştırmanın amacı, Türkçe dersi öğretim programında yer alan "öğrenmeyi öğrenme” yetkinlik alanının öğretmen görüşlerine göre değerlendirilmesidir. Araştırmada nitel araştırma desenlerinden durum çalışması kullanılmıştır. Araştırma, 2018-2019 eğitim-öğretim yılında dokuz sınıf öğretmeniyle yürütülmüştür. Çalışma grubunda yer alan öğretmenler, maksimum çeşitlilik örnekleme tekniğine göre belirlenmiştir. Veriler, yarı yapılandırılmış görüşme formuyla toplanmıştır. Verilerin analizinde, içerik analizi kullanılmıştır. Araştırma sonucunda, öğretmenlerin öğretim programını yeterince incelemedikleri, "yetkinlikler" konusunda yeterli bilgiye sahip olmadıkları belirlenmiştir. Öğretmenler "öğrenmeyi öğrenme" kavramını en çok "kendi kendine öğrenme" olarak tanımlamışlardır. Araştırma bulgularına göre öğretmenler öğrenmeyi öğrenen bireyler yetiştirmek için, sınıflarında en çok "anlamını bilmediği kelime çalışmaları", "metni tahmin etme", "dilbilgisi çalışmaları" ve "hikâye oluşturma” etkinlikleri yapmaktadırlar. Öğretmenlere göre, öğrenmeyi öğrenen bireyin özellikleri bakımından öğrencileri, en çok "araştırma yapma" davranışı sergilemektedirler.

\section{A B S T R A C T}

The aim of this study is to evaluate "learning to learn" competence area in Turkish lesson curriculum, according to teachers' views. Case study, as a qualitative research design, was used in the study. The research was conducted with nine teachers in 2018-2019 academic year. Participants were formed according to maximum diversity sampling technique. The data was collected with semi-structured interview form. Content analysis, was used in the analysis of data. It was determined that, teachers didn't examine the curriculum sufficiently and didn't have enough knowledge about competencies. Teachers define "learning to learn" as "self-learning" mostly. In their classrooms, they mostly performed "vocabulary studies" ,"predict the text", "grammar studies" and "story formation" activities. According to the teachers, in terms of individuals' learning to learn characteristics, their students "conduct research" mostly.

\section{Giriş}

Bilim ve teknolojide yaşanan hızlı değişim, bireyin ve toplumun değişen ihtiyaçları, öğrenme öğretme teori ve yaklaşımlarındaki yenilik ve gelişmeler bireylerden beklenen rolleri de doğrudan etkilemiştir. $\mathrm{Bu}$ değişim bilgiyi üreten, hayatta işlevsel olarak kullanabilen, problem çözebilen, eleştirel düşünen, girişimci, kararlı, iletişim becerilerine sahip, empati yapabilen, topluma ve kültüre katkı sağlayan vb. niteliklerdeki bir bireyi tanımlamaktadır (MEB, 2018). Teknolojide meydana gelen hızlı değişim, bilgi dünyasında kendini daha belirgin hissettirmektedir.

\footnotetext{
* Sorumlu yazar/Corresponding author.

e-posta: caldankarademir@hotmail.com
} 
Bundan dolayı bilgiyi geçici hafızaya yerleştiren, ezberi bir kenara bırakan, bilgiye ulaşılacak kaynakları araştırmayı öğreten, bilginin kalıcı hafızaya yerleşmesini sağlayan öğrenmeyi öğrenme stratejilerini daha da önemli hâle getirmiştir. Artık eğitim, okul duvarlarını aşmıştır. Böylece etkin öğrenim yöntem ve stratejileri de hayatımıza zorunlu olarak girmektedir (Çerçi, 2005).

Kişinin kazandığı bilgiyi beceriye dönüştürmesi gerekir. Bilginin beceriye dönüşmesi onun hayata geçirilmesi veya zihinde referans noktası oluşturması ile gerçekleşir. Bu, bireyin öğrenmesi gereken bir şeydir. Bir bilginin günlük hayata geçirilmesi veya bakış açımızı değiştirmesi, bir başkasının öğretmesi ile gerçekleşmez, bunu bireyin öğrenmesi gerekir. Bu nedenle öğretmenin görevi öğretmek değil, bireylere öğrenecekleri deneyimler ve ortamlar sunmaktır (Özden, 2013). Öğrencilerin okulda öğrendiklerini günlük yaşamlarıyla ilişkilendirebilmeleri öğrenilenlerin kalıcı olmasını sağlayacak ve uzun vadede sadece bireysel değil, aynı zamanda toplumsal gelişimin de gerçekleşmesine katkı sağlayacaktır (Ekmen ve Bakar, 2018).

Öğrenme, büyüme ve vücutta değişik etkilerle oluşan geçici değişmelere atfedilmeyecek, yaşantı ürünü olarak meydana gelen davranışta ya da potansiyel davranıştaki nispeten kalıcı izli değişme (Senemoğlu, 2005) iken, öğrenmeyi öğrenme ise en yalın hâliyle mevcut bilgileri kullanarak yeni durumlar için gerekli bilgiyi üretebilmek demektir. Öğrenmeyi öğrenme düşünsel bir etkinliktir. Herhangi bilgi veya yöntem ile değil, tamamıyla düşünsel kapasiteyle ilgilidir. İnsanın sahip olduğu zekâyı kullanması, düşünme yetilerini geliştirmesi ile mümkündür (Özden, 2013). Dolayısıyla öğrenmeyi öğrenen bireyin özellikleri; daha aktif öğrenen ve üretken, düşünme yetisini ve zekâsını kullanabilen, zorluklarla başa çıabilen şeklinde sıralanabilir. Türkçe dersi de bir ifade ve beceri dersi olduğu için bu derste öğrencilerden beklenen önceki bilgilerini de kullanarak dinleme, konuşma, okuma ve yazma etkinlikleriyle kendilerini yetiştirmeleri ve özgün ürünler üretmeleridir. $\mathrm{Bu}$ süreçte öğretmenin görevi ise daha çok rehberlik konumunda yardım etmek ve yol göstermektir. Öğrenmeyi öğrenme, tüm eğitim-öğretim faaliyetlerinde bireylerin daha etkili ve kalıcı öğrenmeleri açısından büyük önem taşımaktadır. Çünkü öğretim süreci içerisinde bireyin kendisine sunulan bilgiyi ezberlemesi değil anlaması, yorumlaması ve özümsemesi gerektiği kabul edilmektedir. Öğrenmeyi öğrenme kavramı bireylerin öğrenme stilleri ve kullandıkları öğrenme stratejileri gibi özelliklerle ilgilidir (Akın, Çıray ve Sönmez, 2013).

Programda, ilkokulu tamamlayan öğrencilerin gelişim düzeyine ve kendi bireyselliğine uygun olarak ahlaki bütünlük ve öz farkındalık çerçevesinde, öz güven ve öz disipline sahip, gündelik hayatta ihtiyaç duyacağı temel düzeyde sözel, sayısal ve bilimsel akıl yürütme ile sosyal becerileri ve estetik duyarlılığı kazanmış, bunları etkin bir şekilde kullanarak sağlıklı hayat yönelimli bireyler olmalarını sağlama amacı belirtilmiştir (MEB, 2018). Ortak bir anlayış olarak eğitimin, öğrencilerin bilgi düzeyinin değerlendirilmesinden ziyade bilginin birey için anlamlı ve yaşantısal hale getirilmesi esasına dayandırılmıştır (MEB, 2017). Ayrıca ortaokulu tamamlayan öğrencilerin de ilkokulda kazandıkları yetkinlikleri geliştirmek suretiyle millî ve manevi değerleri benimsemiş, haklarını kullanan ve sorumluluklarını yerine getiren, "Türkiye Yeterlilikler
Çerçevesi"nde ve ayrıca disiplinlere özgü alanlarda ifadesini bulan temel düzey beceri ve yetkinlikleri kazanmış bireyler olmalarını sağlama amacı belirtilmiştir (MEB, 2018). Scott'a göre (2014) program geliştirme çalışmalarının temel amacı, öğrencilerin öğrenmeyi öğrenmeleri ve yaratıcılıklarını geliştirecek becerileri ilerletmeleri olarak ifade edilmiştir. Öğretim programlarının amaçlarından anlaşılacağı üzere bireyden yalnızca bilgi sahibi olması değil belli becerileri kazanması ve bu becerileri kullanarak okul dişında da yaşam boyu öğrenmeye devam ederek kendini geliștirmesi, öğrendiklerini yaşama taşıyabilmesi beklenmektedir.

Alan yazın incelendiğinde, 2018 yılı Türkçe dersi öğretim programının incelendiği, değerlendirildiği ve önceki programlarla karşılaştırıldığı (Aslan ve Atik, 2018; Aydın, 2017; Aydın ve Sadioğlu, 2018; Bağc1-Ayrancı ve Mutlu, 2017; Bağcı-Ayrancı ve Pilav, 2017; Bıçak ve Alver, 2018; Çerçi, 2018; Çevik ve Güneş, 2017; Eken ve Öksüz, 2019; Güneş, 2017; Koçoğlu ve Yanpar-Yelken, 2018; Konuk, 2018; Ömeroğlu, 2018; Özcan ve Yıldız, 2018; Özenç, 2018; Söylemez, 2018; Susar-Kırmızı ve Yurdakal, 2019) görülmüştür. Ayrıca yetkinlikler, öğrenmeyi öğrenme ve yaşam boyu öğrenme alanlarında (Akın, Çıray ve Sönmez, 2013; Çerçi, 2005; Direkçi, Akbulut ve Şimşek, 2019; Ekmen ve Bakar, 2018; Mercan, 2011; Pınarcık, Danacı, Deniz ve Eran, 2016) çalışmalara rastlanmıştır. İncelenen alan yazın çerçevesinde 2018 yılı Türkçe dersi öğretim programında yer alan yetkinliklerden biri olan "öğrenmeyi öğrenme" yetkinlik alanının sınıf öğretmenlerinin görüşlerine göre incelendiği herhangi bir araştırmaya rastlanılamamıştır.

Eğitim sistemimiz yetkinliklerde bütünleşmiş bilgi, beceri ve davranışlara sahip karakterde bireyler yetiştirmeyi amaçlar. Öğrencilerin hem ulusal hem de uluslararası düzeyde; kişisel, sosyal, akademik ve iş hayatlarında ihtiyaç duyacakları beceri yelpazeleri olan yetkinlikler, Türkiye Yeterlilikler Çerçevesinde (TYÇ) belirlenmiştir. Anadilde iletişim, yabancı dillerde iletişim, matematiksel yetkinlik ve bilim/teknolojide temel yetkinlikler, dijital yetkinlik, öğrenmeyi öğrenme, sosyal ve vatandaşlıkla ilgili yetkinlikler, inisiyatif alma ve girișimcilik ile kültürel farkındalık ve ifade olmak üzere sekiz anahtar yetkinlik belirlemiştir (MEB, 2018). Yetkinlikler incelendiğinde, okul dışında da devam eden yaşam boyu bir öğrenme anlayışı benimsendiği anlaşılmaktadır. Öğrenmeyi öğrenme yetkinliği, bireyin kendi öğrenme özelliklerini tanıması, öğrenmede yararlanılan stratejileri bilip, seçmesi ve bu stratejileri kullanabilmesi olarak ifade edilmektedir (Özer, 2008). Bu süreçte bireylerin ezber yerine sorgulaması gerektiği vurgulanmaktadır. Bu sayede bilginin ihtiyaç ve amaçlarla ilişkilendirilmesi sağlanır ve öğrenme gerçekleşir. Ayrıca analiz, sentez ve yorum yapabilme becerileri de gelişir (Meydan, 2010). Bu nedenle bu özelliklere sahip bireyler yetiştirmede, öğretim programlarına paralel uygulamaları gerçekleştiren öğretmenlere büyük görev ve sorumluluklar düşmektedir. Üst bilişsel becerilerin kullanımına yönlendiren, anlamlı ve kalıcı öğrenmeyi sağlayan, sağlam ve önceki öğrenmelerle ilişkilendirilmiş, diğer disiplinlerle ve günlük hayatla bütünleşmiş, değerler, beceriler ve yetkinlikler çerçevesinde bir öğretim programları toplamı (MEB, 2018) şeklinde tanımlanan programın, öğretmenler tarafindan "öğrenmeyi öğrenme" yetkinlik alanının nasıl değerlendirildiği 
önemlidir. $\mathrm{Bu}$ araştırmada, yapılan değerlendirmeler kapsamında öğrenmeyi öğrenme yetkinlik alanının işlevselliği ve varsa sorunları için çeşitli öneriler geliştirilebilecektir. İlkokul düzeyi dikkate alındığında, sınıf öğretmenlerinin farkındalıkları ve sınıf içi uygulamalarının önemli olduğu düşüncesinden hareketle, bu araştırma, MEB tarafindan 2017 yılında güncellenen ve 2018-2019 eğitim öğretim yılında uygulamaya konan 2018 yılı Türkçe dersi öğretim programında yer alan yetkinlikler bölümündeki "öğrenmeyi öğrenme" yetkinlik alanının sınıf öğretmenlerinin görüşlerine göre değerlendirilmesini amaçlamaktadır. Bu amaç doğrultusunda aşağıdaki sorulara yanıt aranmıştır.

-Öğretmenlerin “öğrenmeyi öğrenme” yetkinlik alanına ilişkin görüşleri nelerdir?

-Öğretmenler sınıf içi öğrenme öğretme süreçlerinde “öğrenmeyi öğrenme” yetkinliğini nasıl kullanmaktadır?

-Öğretmenlerin öğrenmeyi öğrenen bireylerin özelliklerine ilişkin görüşleri nelerdir?

-Öğretmenlerin öğrenmeyi öğrenen bireyler yetiştirmelerine ilişkin görüşleri nelerdir?

\section{Yöntem}

Bu bölümde araştırma modeli, çalışma grubu, veri toplama arac1, verilerin toplanması, verilerin analizi ve geçerlikgüvenirlik yer almaktadır.

\subsection{Araştırma Modeli}

$\mathrm{Bu}$ araştırma, nitel araştırma modellerinden durum çalışması ile desenlenmiştir. Nitel yöntemler derin ve ayrıntılı konularda çalışmaya imkân verir (Patton, 2018). Durum çalışmasında amaç, belirli bir duruma ilişkin sonuçlar ortaya koymaktır. Durum çalışması araştırması, bağlamı ve çalışılan durumla/durumlarla ilişkisi, diğer karmaşık koşulların durumunu/durumlarını anlamanın ayrılmaz bir parçası olduğunu varsayar (Yin, 2017). Bu araştırmada, Türkçe dersi öğretim programı yetkinlikler bölümünde yer alan öğrenmeyi öğrenme yetkinlik alanının sınıf öğretmenlerinin görüşlerine göre derinlemesine betimlenebilmesi için durum çalışması deseni seçilmiştir. Durum çalışması desenlerinden iç içe geçmiş tek durum deseni kullanılmıştır.

\section{2. Çalışma Grubu}

Araştırmanın çalışma grubunu 2018-2019 eğitim öğretim yılında Burdur ilinde bulunan iki ilçede sınıf öğretmeni olarak görev yapan öğretmenler oluşturmaktadır. Çalışma grubu oluşturulurken, amaçlı örnekleme tekniklerinden biri olan maksimum çeşitlilik örnekleme tekniğinden yararlanılmıştır. Amaçlı örnekleme kapsamındaki maksimum çeşitliliğin amac1, çeşitliliğin büyük ölçüde geniş kapsamlı olan merkezi temaları yansıtması ve tanımlamasıdır. $\mathrm{Bu}$ bağlamda araştırmacı, heterojen bir örneklem grubu oluşturmaya çalışır (Patton, 2018). Maksimum çeşitliliğe dayalı örneklem oluşturmadaki amaç, göreli olarak küçük bir örneklem oluşturmak ve bu örneklemde çalışılan probleme taraf olabilecek bireylerin çeşitliliğini maksimum derecede yansıtmaktır (Yıldırım ve Şimşek, 2016). Bu nedenle araştırmanın çalışma grubu oluşturulurken cinsiyet, kıdem, okuttuğu sınıf, bu okuldaki görev süresi, eğitim durumu ve okulun bulunduğu sosyoekonomik çevre dikkate alınmıştır. Araştırmaya katılan öğretmenlere ait kişisel bilgiler Tablo 1'de verilmiştir. Tablo 1. Öğretmenlere Ait Kişisel Bilgiler

\begin{tabular}{ccccccc}
\hline Öğr. & Cins. & Kıd. & $\begin{array}{c}\text { Okut. } \\
\text { Sin. }\end{array}$ & $\begin{array}{c}\text { Bu } \\
\text { okuldaki } \\
\text { görev } \\
\text { süresi }\end{array}$ & $\begin{array}{c}\text { Eğit. } \\
\text { Dur. }\end{array}$ & $\begin{array}{c}\text { Okulun } \\
\text { Bul. } \\
\text { Sos.Eko. } \\
\text { Düzey }\end{array}$ \\
\hline Ö1 & E & 5 & 3 & 1 y1l & Lisans & Orta \\
\hline Ö2 & K & 5 & 2 & 1 y1l & Lisans & Orta \\
\hline Ö3 & E & 31 & 3 & 16 y1l & Ön lis. & Düşük \\
\hline Ö4 & K & 6 & 4 & 2 y1l & Lisans & Orta \\
\hline Ö5 & E & 28 & 1 & 5 y1l & Lisans & Yüksek \\
\hline Ö6 & $\mathrm{K}$ & 17 & 2 & 2 y1l & Lisans & Yüksek \\
\hline Ö7 & $\mathrm{K}$ & 12 & 4 & 9 y1l & Lisans & Orta \\
\hline Ö8 & $\mathrm{E}$ & 14 & 1 & 3 y1l & Lisans & Düşük \\
\hline Ö9 & $\mathrm{K}$ & 12 & 3 & 5 y1l & Lisans & Düşük \\
\hline
\end{tabular}

Tablo 1 incelendiğinde, araştırmaya katılan öğretmenlerin beşi kadın, dördü erkektir. İki öğretmen 1-5 yıl arası, bir öğretmen 6-10 yıl arası, üç öğretmen 11-15 yıl arası, bir öğretmen 16-20 yıl arası ve iki öğretmen de 21 yıl ve üzeri mesleki kıdeme sahiptir. Her sınıf düzeyinde öğretmen araştırmaya katılmıştır. Sekiz öğretmen lisans, bir öğretmen ise ön lisans eğitim durumuna sahiptir. Üç okulun düşük, dört okulun orta ve iki okulun da yüksek sosyo-ekonomik duruma sahip olduğu görülmektedir.

\subsection{Veri Toplama Arac1}

Nitel araştırmalarda kullanılan görüşmelerin en güçlü özelliği göremediklerimiz hakkında bilgi edinme ve gördüklerimiz hakkında ise alternatif açıklamalar yapma fırsatı vermeleridir (Glesne, 2015). Bu araştırmada veriler, araştırmacılar tarafından hazırlanan yarı yapılandırılmış görüşme formu kullanılarak elde edilmiştir. Yarı yapılandırılmış görüşme, araştırmacı tarafından önceden belirlenmiş ya da görüşme sırasında ortaya çıkan konulara göre yeni soruların da sorulabildiği bir görüşme yöntemi olarak nitel araştırmalarda yaygın olarak kullanılan bir veri toplama tekniğgidir (Güler, Halıcıoğlu ve Taşğın, 2015).

Alan yazın taraması sonrasında hazırlanan yarı yapılandırılmış görüşme formu için uzman görüşü alınmıştır. Uzman görüşüne göre alan yazında öğrenmeyi öğrenme kavramının alt boyutları da incelenmiş ve görüşme sorularının ifade biçimi değiştirilmiştir. Görüşme formunda yer alan soruların anlaşılırlığını belirlemek için pilot görüşmeler yapılmış ve anlam bozukluğu anlaşılan ifadeler düzeltilerek, pilot görüşmelerden sonra forma son şekli verilmiştir. Pilot görüşmelerde 5 soru yer almış ve hazırlanan ön görüşme formu 2 ögrretmen ile yaklaşık 20 'şer dakikalık süreler hâlinde gerçekleştirilmiştir. Pilot görüşmelerden sonra görüşme formuna son hâli verilmiş ve 6 sorudan oluşan yarı yapılandırılmış görüşme formu hazırlanmıştır.

\subsection{Verilerin toplanmas1}

Çalışma grubunda yer alan öğretmenlerle görüşmeye gönüllü olup olmadıkları teyit edilmiş, görüşme için görüşme yeri ve zamanı kararlaştırılmıştır. Öğretmenlerin ders saatleri dışında görüşmeler okulda görüşmeye müsait yerlerde gerçekleştirilmiştir. Görüşme formunun son şekli ile yapılan görüşmeler 25-38 dakika sürmüştür. 


\subsection{Verilerin Analizi}

Araştırma verilerinin analizi, nitel veri analizi tekniklerinden içerik analizi kullanılarak yapılmıştır. İçerik analizi, hacimli olan nitel materyali alarak, temel tutarlılıkları ve anlamları belirlemeye yönelik herhangi bir nitel veri indirgeme ve anlamlandırma çabası girişimlerini ifade etmek için kullanılmaktadır (Patton, 2018). Elde edilen veriler bilgisayar ortamına aktarılarak araştırmanın amac1, alt problemleri ve görüşme formunda yer alan sorular doğrultusunda gruplanmıştır. Ham veri metinleri içerik analizi için satır satır okunmuş ve okumalar neticesinde elde edilen bulgular doğrultusunda nitel veri setinde ortaya çıkan kodlar listelenmiştir. Örtüşen kodlar tespit edilmiş ve ortak temalara ulaşılmaya çalışılmıştır.

\subsection{Geçerlik ve Güvenirlik}

Nicel çalışmalarda kullanılan geçerlik ve güvenirlik kavram ve kriterlerinin aynı şekilde nitel çalışmalarda kullanılmasının zor olmasından dolayı, nitel araştırmacılar aynı kriterleri yansıtan farklı kavramlar kullanmışlardır. Guba ve Lincoln (1989), nicel çalışmalarda kullandığı iç geçerlik, dış geçerlik, güvenirlik ve objektiflik kavramlarının yerine sirasıyla inandırıcılık, transfer edilebilirlik, değişmezlik ve teyit edilebilirlik kavramlarını kullanmıştır (aktaran: Güler, Halıcıoğlu ve Taşğın, 2015). Yöntemler ve prosedürler geçerliği garanti etmese de sonuçların inanırlığını arttırır. Katılımcı teyidi verilerden ve çalışılan kişilerden gelen sonuçlardan sistematik olarak dönüt almak olarak ifade edilmektedir (Maxwell, 2018). Bu araştırmada inandırıcılığın sağlanabilmesi için görüşme yapılan öğretmenlerden katılımcı teyidi alınmıştır. Patton'a (2018) göre inanılırlı̆̆ üçgenlemedir. Tekil gözlemci ya da analizci yerine çoklu araştırmacı ya da analizci kullanılmasıyla elde edilen üçgenleme, çoklu analizci üçgenlemesi olarak ifade edilmektedir. Verilerin analizi sürecinde ise birden fazla araştırmacının bakış açısı göz önünde bulundurularak, kodlamalarda uyuşum yüzdesi hesaplanmış ve inandırıcılık sağlanmaya çalışılmıştır. İki araştırmacı tarafından yapılan analizler arasında tutarlık incelemesi yapılmıştır. Güvenirlik katsayısını hesaplamada, $\mathrm{P}=(\mathrm{Na} / \mathrm{Na}+\mathrm{Nd}) \times 100$ (Miles ve Huberman, 2016) formülü kullanılmıştır. Hesaplama sonucunda, iki araştırmacı arasında birinci görüşme (Ö5) kaydına ait \%73.07, ikinci görüşme (Ö9) kaydına ait \%79.16 oranında uyum tespit edilmiştir. İki kodlayıcı arası güvenirlik hesaplaması Tablo 2'de sunulmuştur:

Tablo 2. İki Kodlayıcı Arası Güvenirlik

\begin{tabular}{lccc}
\hline Veri Seti & $\begin{array}{c}\text { Görüş̧ } \\
\text { Birliği } \\
\text { Sayısı (Na) }\end{array}$ & $\begin{array}{c}\text { Görüş Ayrılığı } \\
\text { Sayı1 (Nd) }\end{array}$ & $\begin{array}{c}\text { Güvenirlik } \\
(\mathrm{P})\end{array}$ \\
\hline $\begin{array}{l}\text { Ö5'e ilişkin } \\
\text { görüşme kayd } 1\end{array}$ & 19 & 7 & 73.07 \\
\hline $\begin{array}{l}\text { Ö9'a ilişkin } \\
\text { görüş̧me kayd }\end{array}$ & 19 & 5 & 79.16 \\
\hline
\end{tabular}

Erlandson, Harris, Skipper ve Allen (1993) araştırma sonuçlarının "aktarılabilirliğini (transfer edilebilirliğini)" arttırmak için ayrıntılı betimleme ve amaçlı örnekleme yöntemlerini önermektedir. Nitel araştırma sonuçlarının aktarılabilirliği, dayandığı verilerin yeterli düzeyde betimlenmesine bağlıdır. Ayrıntılı betimleme ham verinin ortaya çıkan kavram ve temalara göre yeniden düzenlenmiş bir biçimde okuyucuya yorum katmadan aktarılması ve doğrudan alıntılara yer verilmesidir. Amaçlı örnekleme yöntemi, nitel araştırmalarda aktarılabilirliği arttırmak için hem tipik olarak karşımıza çıkan olay ve olguları hem de bunların değişkenlik gösteren özelliklerini ortaya koyma amacını güder. Bu araştırmada ise aktarılabilirliği sağlamak için amaçlı örnekleme kullanılmıştır. Ayrıca elde edilen veriler derinlemesine analiz edilmiş ve bulgular bölümünde doğrudan alıntılara yer verilmiştir.

Güvenirlik ile paralel anlama sahip olan değişmezlik kavramı için yapılması gereken, veri toplama ve analiz safhalarının detaylı olarak anlatılmasıdır. $\mathrm{Bu}$ süreçte kapsamlı bir veri kullanımı ve detaylı anlatım gereklidir. Kapsamlı ve zengin veriye sahip olmak önemlidir. Ancak veri toplama aşamasında bir yerden sonra katılımcıların söyledikleri önceki katılımcıların söylediklerini tekrar ediyorsa ve yeni bulgular ortaya çıkmıyorsa, bu aşamadan sonra veri toplamaya son verilmelidir. Ayrıca çalışmanın bulguları sunulurken okuyucuya daha geniş bilgi vermek için uygun tabloların kullanılması önemlidir (Güler, Halıcıoğlu ve Taşğın, 2015). Bu araştırmada ise güvenirliği sağlamak için veri toplama ve analiz safhaları detaylı olarak açıklanmış, veri toplama aşamasında ise verilerin yeterli doygunluğa ulaştığg fark edildiğinde görüşmelere son verilmiştir. Araştırma bulguları sunulurken uygun tablolar kullanılmış, çalışma grubunda yer alan katılımcıların özellikleri, veri analizi sürecinde ulaşılan kodlar ve temalar uygun tablolarda sunulmuştur. Son olarak ise araştırmada teyit edilebilirlik kapsamında, araştırma sürecinde öğretmenlerle ses kaydı ve elle not alınarak görüşme kayıtları gerçekleştirilmiştir. Ham veriler analiz aşamasında açık kalmıştır. Bulgular sunulurken oluşturulan anlamlar ham veri metni ile karşılaştırılarak yazılmıştır. Ayrıca analiz aşamasında yapılan kodlamalar gerektiğinde böyle bir incelemeye sunulması için saklanmıştır. Çünkü Erlandson ve diğerleri (1993) bu süreçte araştırmacıdan beklenenin, ulaşılan sonuçları toplanan verilerle sürekli olarak teyit etmek ve okuyucuya mantıklı bir açıklama sunmak olduğunu belirtmişlerdir. Ayrıca teyit incelemesinde, araştırmanın sonuçları ham verilerle karşılaştırılır.

\section{Bulgular}

Bu bölümde öğretmenlerin "öğrenmeyi öğrenme” yetkinlik alanına ilişkin görüşlerine ilişkin bulgular alt problemlere göre başlıklar altında verilmiştir.

\section{Öğrenmeyi Öğrenme Temasına Yönelik Öğretmen Görüşlerine Ait Bulgular}

Araştırmaya katılan öğretmenlerin "öğrenmeyi öğrenme" yetkinlik alanına ilişkin görüşleri Tablo 3 'te verilmiştir. 
Tablo 3. Öğretmenlerin Öğrenmeyi Öğrenme Yetkinlik Alanına İlişkin Görüşleri

\begin{tabular}{|c|c|c|}
\hline \multicolumn{2}{|c|}{ Öğrenmeyi öğrenme } & $\mathrm{n}$ \\
\hline \multirow{5}{*}{ 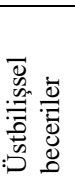 } & Kendi kendine öğrenme & 7 \\
\hline & Öğretmenlerin rehber konumunda olmas1 & 4 \\
\hline & Sorgulayıcı olma ve soru sorma & 3 \\
\hline & Ezberden uzak kalıcı öğrenme & 3 \\
\hline & Farkında olma & 3 \\
\hline \multirow{4}{*}{ 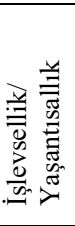 } & $\begin{array}{l}\text { Yaratıcılığı geliştirme, üretkenliği } \\
\text { sağlama }\end{array}$ & 5 \\
\hline & Bilgiyi kullanabilme & 4 \\
\hline & $\begin{array}{l}\text { Özgüveni geliştirmesi, kendini ifade } \\
\text { edebilme }\end{array}$ & 2 \\
\hline & Araştırma yapma & 1 \\
\hline
\end{tabular}

Tablo 3 incelendiğinde araştırmaya katılan 7 öğretmen öğrenmeyi öğrenme kavramını öğrencilerin kendi kendilerine öğrenmesi olarak nitelendirmektedirler. Kendi kendine öğrenme aslında öğrencinin kendi isteğiyle ve çabasıyla öğrenmesi, bilginin veya öğrenmenin peşine düşmesi, nasıl öğreneceklerini ya da bilgiye nasıl ulaşacaklarını kendilerinin öğrenmesidir. Beş öğretmen, öğrenmeyi öğrenen bireylerde yaratıcılığın geliştiğini ve üretkenlik sağlandığını düşünmektedir. Dört öğretmen öğrenmeyi öğrenme sürecinde bilgiyi kullanabilme noktasında görüş belirtirken diğer başka 4 öğretmen ise öğretmenlerin rehber konumunda bulunması gerektiğini belirtmişlerdir. Üç öğretmen öğrencilerin sorgulayıcı özellikte olmasının, ezberden uzak bir şekilde öğrenmenin daha kalıcı olacağı yönünde görüşlerini ifade etmişlerdir. İki öğretmen bilginin, öğrenmenin ve kaynakların farkında olmaktan bahsederken başka 2 öğretmen de özgüveni geliştirmesi ve kendini ifade edebilmesi olarak belirtmiştir. Araştırmaya katılan öğretmenlerden sadece biri öğrenmeyi öğrenme kavramında araştırma yapma şeklinde görüş belirtmiştir.

Araştırmaya katılan öğretmenlerin büyük bir çoğunluğu öğrenmeyi öğrenme kavramını "kendi kendine öğrenme" olarak nitelendirmektedir. Bazı öğretmenlerin görüşleri aşağıda verilmiştir.

"Öğrenciler kendi isteğiyle öğrenmesi zaten çok daha güzel. Bizim de istediğimiz aslinda ögrencinin okula öğrenme isteğiyle gelip kendi çabasıyla bir şeyler ögrenmeye çalıșması, bilgiyi istemesi." (Ö2)

"Öğrenmeyi ögrenme kavramını, çocuklara direkt bilgi vermektense nasıl öğreneceklerini, bilgiye nasıl ulaşacaklarını kendilerinin ögrenmesi şeklinde tanımlayabilirim." (Ö6)

"Öğrenmeyi öğrenmenin özellikleri; çocuğun bilgiye kendisinin ulaşmasını hedeflediğini, ögrencinin bilgiye nasıl ulaşacağını keşfetmesi, çevresindeki olanakları kullanması gerektiği, mevcut kaynakların da farkına varmasl ve bu kaynakları etkin bir şekilde kullanması şeklinde söyleyebilirim." (Ö9)

Öğrenmeyi öğrenme kavramını "yaratıcılığı geliştirme, üretkenliği sağlama" olarak düşünen bazı öğretmenlerin görüşleri ise şu şekildedir.
"Öğrencilerim bazen verdiğim skeçlere bağll kalmadan kendileri de eklemeler yapabiliyor (el hareketleri, konuşmalar, roller üretmek gibi). Bu tür etkinliklerde yaratıcılıkları da gelişiyor.” (Ö7)

“Öğrenmeyi öğrenme demek insanın kendi başına bir şeyleri yapabilmesi demek. Yani kendi üretken olan kişi demek." (Ö3)

Öğrenmeyi öğrenme kavramını "öğretmenlerin rehber konumunda olması" şeklinde belirten öğretmenlerin bazı görüşleri de aşağıda verilmiştir.

"Öğretmenin bire bir sürekli empoze eden sürekli anlatan değil yol gösterici kllavuz olması gerektiğini düşünüyorum." (Ö5)

"Öğrenmeyi öğrenme deyince, çocukların bir işi başarabilmesi, kendi çabalarlyla konuyu ögrenebilmesi, öğretmenin daha çok rehberlik konumunda olması, öğrenciyi yönlendirmesi, ögrencinin buluş yoluyla öğrenme stratejilerini kullanmasl şeklinde olduğunu biliyorum." (Ö8)

Öğrenmeyi öğrenme kavramını "sorgulayıcı olma, soru sorma" şeklinde ifade eden öğretmenlerin bazılarının görüşleri aşağıda verilmiştir.

"Ayrica sorgulayan bireysindir de. Öğrencilerimizden de beklenen sorgulayarak yeni bilgiler ögrenmesidir. Düz bir kalıp olmaktansa yeni kalıplar oluşturmaktır.” (Ö1)

"Çocuklar genellikle takıldıkları yerlerde özellikle eş anlaml zit anlaml kelimelerde ya da yeni ögrendikleri kelimelerde sürekli gelirler, sorarlar. Çok sorgucu ögrencilerimiz var. ” (Ö3)

Araştırmaya katılan öğretmenlerin büyük bir çoğunluğu, Türkçe dersi öğretim programını incelemediğini belirtseler de öğrenmeyi öğrenme kavramına anlam yükleyerek tanımlama yaptıkları anlaşılmaktadır. Programı inceleyen öğretmenler de yetkinlik alanlarını değil genel olarak göz attığını, yazı bölümünü incelediğini belirtmiştir.

"Türkçe dersi öğretim programını detayl inceleyemedim. Yazı (dik temel harfleğik yazı) bölümünü incelemiştim. Yetkinlikler kısmını incelemedim. Programda öğrenmeyi öğrenmenin yer aldığını bilmiyordum. " (Ö6)

Evet, programı incelediğimiz kadar bildiğimiz kadarlyla zaten önceden ögretmen olduğum için bilgimiz var. Yeni programları takip etmeye çalışlyoruz. (Ö5)

Araştırmaya katılan öğretmenlerin öğrenmeyi öğrenme kavramına yükledikleri anlam, üst bilişsel beceriler ve işlevsellik olarak ön plana çıkmaktadır. Öğrenilen bilgilerin yaşantıya dönüştürülmesi hiç şüphesiz kalıcılık açısından son derece gereklidir. Ayrıca öğrencilerin bilgiye nasıl ulaşacaklarını ve kendi kendine öğrenme yollarını da bilmesi zihinsel süreçleri kullanma bakımından oldukça önemlidir.

\section{Öğrenmeyi Öğrenme Yetkinliğinin Sınıf İçi Öğrenme- Öğretme Süreçlerinde Kullanma Durumu Temasına Yönelik Öğretmen Görüşlerine Ait Bulgular}

Araştırmaya katılan öğretmenlerin "öğrenmeyi öğrenme" yetkinlik alanında sınıf içi öğrenme-öğretme süreçlerinde 
kullanma durumlarına ilişkin görüşleri Tablo 4'te verilmiştir.

Tablo 4. Öğretmenlerin Öğrenmeyi Öğrenme Yetkinlik Alanında Sinıf İçi Öğrenme-Öğretme Süreçlerinde Kullanma Durumlarına İlişkin Görüşleri

\begin{tabular}{|c|c|c|}
\hline \multicolumn{2}{|c|}{ Öğrenme-öğretme süreci } & $\mathrm{n}$ \\
\hline \multirow{9}{*}{$\begin{array}{l}\bar{d} \\
\stackrel{0}{0} \\
\stackrel{0}{0}\end{array}$} & Anlamını bilmediği kelime çalışması & 8 \\
\hline & Metni tahmin etme & 6 \\
\hline & Metne başlık önerme & 4 \\
\hline & Hikâye tamamlama & 4 \\
\hline & Özgün şiir yazma, hikâye oluşturma & 4 \\
\hline & Görselleri yorumlama & 3 \\
\hline & Okuma etkinlikleri & 2 \\
\hline & Araştırma ödevleri & 2 \\
\hline & Metnin olay örgüsü & 1 \\
\hline \multirow{6}{*}{ 营 } & Dil bilgisi çalışmaları & 6 \\
\hline & Hikâye oluşturma & 3 \\
\hline & Şiir yazma & 2 \\
\hline & Hikâye tamamlama & 2 \\
\hline & Deyim ve atasözü çalışmaları & 2 \\
\hline & Canlandırma & 1 \\
\hline
\end{tabular}

Tablo 4 incelendiğinde araştırmaya katılan 8 öğretmen öğrenmeyi öğrenme yetkinlik alanında öğrencilerin kendi öğrenme eylemini etkili zaman ve bilgi yönetimini de kapsayacak şekilde bireysel etkinliklerde anlamını bilmediği kelime çalışması yaptığını söylemişlerdir. Öğretmenler anlamını bilmediği veya yeni öğrendiği kelime çalışmasında öğrencilerin sözlükten araştırma, cümle içinde kullanma, görsellerle eşleştirme, resim yapma, cümleden kelimenin anlamını tahmin etme gibi etkinliklerle kelimenin anlamını öğrenmeye çalıștıklarını belirtmişlerdir. Altı öğretmen metni tahmin etme etkinliği yaptırdığını, bu etkinlikte öğrencilerin metni görsellerinden veya başlığından hareketle tahmin ettiklerini söylemişlerdir. Dört öğretmen metne başlık önerme, hikâye tamamlama ve özgün şiir yazma ile hikâye oluşturma etkinliği düzenlediklerini belirtmişlerdir. $\mathrm{Bu}$ tür etkinliklerin öğrencilerin yaratıcılıklarını geliştirme adına oldukça yararlı olacağ 1 söylenebilir. Araştırmada 3 öğretmen görselleri yorumlama etkinliğini yaptırdığını bildirmiştir. İki öğretmen okuma etkinlikleri yaptırırken diğer başka 2 öğretmen de araştırma ödevleri verdiğini ifade etmişlerdir. Bireysel olarak sadece 1 öğretmen sınıfta metnin olay örgüsünü çıkardıklarını belirtmiştir. Araştırmada grupla yapılan etkinliklerde dil bilgisi çalışmaları 6 öğretmen görüşü ile en çok tercih edilen çalıșma olmuştur. Dil bilgisi çalışmaları daha çok eş anlamlı kelimeler, zıt anlamlı kelimeler ve hece çalışmaları gibi etkinliklerdir. Üç öğretmen hikâye oluşturma etkinliği yaptırdığını belirtmiştir. İki öğretmen şiir yazma etkinliği, diğer 2 öğretmen hikâye tamamlama etkinliği, başka 2 öğretmen de deyim ve atasözü çalışmaları yaptırdığını bildirmiş̧lerdir. Sadece 1 öğretmen grupla yaptığı etkinliklerde canlandırma etkinliği yaptıklarını söylemiştir.

Öğretmenlerin öğrenmeyi öğrenme yetkinlik alanında öğrencilerin kendi öğrenme eylemini etkili zaman ve bilgi yönetimini de kapsayacak şekilde bireysel olarak sınıf içi öğrenme-öğretme süreçlerinde kullanma durumlarına ilişkin bazılarının görüşleri aşağıda verilmiştir.

“Anlamını bilmediği kelimeyi önce tahmin etme, anlamını bilmediği kelimenin geçtiği cümleyi tekrar okuyup oradan çıkarımda bulunma daha sonra da sözlükten kontrol edip tahmininin doğru olup olmadığını bulma, cümle içinde kullanma gibi.” (Ö8)

"Görsellerden veya başliktan metnin konusunu tahmin etme şeklinde de etkinliklerimiz oluyor.” (Ö6)

"Ayrıca işlediğimiz metinler ile ilgili farkl başlıklar önerme, anlamını yeni öğrendikleri kelimelerin, atasözlerinin ve deyimlerin resimlerini yapma ile bu metne uygun sen olsan nasil resim çizerdin gibi etkinliklerle yaratıcılıklarının geliştiğini düşünüyorum. Dilbilgisi konuları ise grup çalışması şeklinde geçiyor. Bu tür etkinlikler genelde kes-yapıştır şeklinde oluyor. Atasözü ve deyimleri canlandırma, konu ile ilgili şarkı uydurma grupla yaptı̆̆ımız diğer örneklerdir.” (Ö9)

"Resimleri yorumluyoruz, resim gösteriyoruz, o resimleri yorumluyorlar veya o resimle ilgili hikâye oluşturuyorlar ya da kelimelerden hikâye oluşturuyorlar bireysel olarak kendi başlarına. O da kendilerini daha rahat ifade etmelerini sağllyor çocukların.” (Ö4)

“Ayrıca, hikâyenin sonunu getirme, görsellerle metni ilişkilendirme ve görsellerden hareketle metni tahmin etme de bireysel olarak Türkçe derslerimizde yaptığımız etkinliklerdir." (Ö1)

Öğretmenlerin öğrenmeyi öğrenme yetkinlik alanında öğrencilerin kendi öğrenme eylemini etkili zaman ve bilgi yönetimini de kapsayacak şekilde grupla sınıf içi öğrenmeöğretme süreçlerinde kullanma durumlarına ilişkin bazılarının görüşleri ise şu şekildedir:

"Grupla yaptığımız etkinliklere örnek verecek olursam, özellikle sinıfça hikâye yazıyoruz. Ben bir cümleyle başlatıyorum hikâyeyi. Strayla her ögrenci olayı takip ederek kendi istediği yöne çekerek bir cümle daha söylüyor. Arkadaşına sıra geçince o da bir cümle söylüyor. Bu şekilde bütün sinıf kendi cümlesiyle bütün bir hikâye oluşturmuş oluyoruz. Bunu bazen yazıyla da yapıyoruz. Kâğt dolaşıyor, kâğıdın ardı sıra yazma devam ediyor ve bunu sonra okuduğumuzda hikâyeyi bütün sınıf daha çok beğeniyor. ” (Ö2)

"Atasözleri ve deyim kartlarımız var. Sinıfi ikiye bölüyorum. Grubun birisi kartı gösteriyor diğer grup tahmin etmeye çallşlyor. Bu kartlarda o deyim ve atasözü ile ilgili resimler var. Eş anlaml kelimeler yarışması yapıyoruz. İki grup sıraya geçiyor. Kelimeyi soruyorum. Bilen grupta kallyor bilemeyen sirasına geçip oturuyor. Bu şekilde etkinlik bitene kadar devam ediyoruz. Çok faydal olduğunu düşünüyorum. Kelimeyi daha iyi düşünüyorlar, kalıcılı̆̆ artıyor." (Ö7)

"Grupça hikâye tamamllyorlar. Grup olarak yazdıklarında beraber düşünüp karar veriyorlar şöyle yazalım mi, yok şöyle yazalım, hayır daha ilginci işte şunu yazalım, hepsi beraber karar veriyorlar. O cümleyi hikâyeyi tamamliyorlar." (Ö3)

Araştırmaya katılan öğretmenlerin sınıf içinde gerek bireysel olsun gerekse grupla yaptıkları uygulamalar olsun öğrencilerinde öğrenmeyi öğrenmeye yönelik oldukça fazla etkinliklere yer verdikleri görülmektedir. Öğrencilerin Türkçe dersinde öğrenecekleri konularda bu tür bireysel ve grupla yapılan uygulamaların olması hem kalıcılığı arttıracak hem de birbirleriyle olan etkileşimini olumlu 
yönde etkileyecektir. İlkokul çağında bulunan öğrencilerin bilişsel, duyuşsal ve devinişsel özellikleri düşünüldüğünde öğrenmeyi öğrenme yetkinliğini kazanabilmeleri için bu tür etkinliklerin sınıf ortamında yapılıyor olması oldukça önemli ve değerlidir.

\section{Öğrenmeyi Öğrenen Bireylerin Özellikleri Temasına Yönelik Öğretmen Görüşlerine Ait Bulgular}

Araştırmaya katılan öğretmenlerin öğrenmeyi öğrenen bireylerin özelliklerine ilişkin görüşleri Tablo 5'te verilmiştir.

Tablo 5. Öğretmenlerin Öğrenmeyi Öğrenen Bireylerin Özelliklerine İlişkin Görüşleri

\begin{tabular}{|c|c|c|}
\hline \multicolumn{2}{|c|}{ Öğrenmeyi öğrenen bireylerin özellikleri } & $\mathrm{n}$ \\
\hline \multirow{6}{*}{ 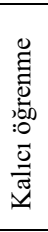 } & Araştırma yapma & 7 \\
\hline & Sorgulayıc1 olma, soru sorma & 6 \\
\hline & Kendi kendine öğrenme & 5 \\
\hline & Farkinda olma & 4 \\
\hline & Anlatma, paylaşımcı olma & 3 \\
\hline & Merakl1 & 3 \\
\hline 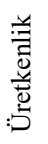 & Yaratıcı olma & 5 \\
\hline
\end{tabular}

Tablo 5 incelendiğinde araştırmaya katılan öğretmenler öğrencilerin öğrenmeyi öğrenen bireylerin özelliklerini Türkçe dersinde en çok araştırma yaparak gösterdiklerini belirtmektedirler. Yedi öğretmen öğrencilerinin bilmedikleri veya yeni öğrendikleri konu hakkında kendilerinin araştırma yapmak istediklerini, 6 öğretmen ise öğrencilerin sorular sorarak, araştırma yaparak aslında sorgulayıcılıklarının da geliştiğini belirtmişlerdir. Beş öğretmen öğrencilerinin Türkçe dersinde yaratıcı bireyler olduklarını, bunu da özgün hikâyeler ve şiirler yazarak veya anlamını yeni öğrendiği kelimelerle yeni cümleler kurarak gösterdiklerini ifade etmişlerdir. Beş öğretmen öğrencilerinin farklı sorular sorarak, evde kendisi araştırma yaparak, konuyu önceden öğrenip gelerek, yeni öğrendiklerini irdeleyerek kendi kendine öğrendiklerini düşünmektedir. Dört öğretmen öğrencilerinin yeni konu öğrenirken nasıl öğreneceklerinin veya konuyu işlerken neden onu işlediklerinin farkında olduklarını söylemişlerdir. Üç öğretmen öğrencilerinin bilmedikleri veya öğrenecekleri konularda meraklı olduklarını ve o merak ettikleri hakkında sorular sorduğunu, araştırma yapmak istediklerini bildirmişlerdir. Diğer başka 3 öğretmen ise öğrencilerinin öğrendikleri konuları sınıfta veya başka bir ortamda arkadaşlarına anlattıklarını, paylaştıklarını bu şekilde de öğrenmelerinin de kalıcı olduğunu belirtmiştir. Tablo 5 incelendiğinde araştırmaya katılan öğretmenlerin öğrencilerinin öğrenmeyi öğrenen bireylerin özelliklerini Türkçe dersinde ortaya koyduklarını söylemek mümkündür.

Öğretmenlerin öğrenmeyi öğrenen bireylerin özelliklerine ilişkin Türkçe dersinde öğrencilerinin "araştırma yapma" davranışına ait görüşlerinden bazıları aşağıda verilmiştir.

“ Öğretmenim şunu yapalım, bu etkinliğ $i$ yapalım diye kendileri ögrenmek istiyor, araştırmak istiyorlar. Bunu biz araştıralım diyorlar, fikir allyorlar benden. .". (Ö4)
"Öğrencilerim, merak ettiği konularda veya bilmedikleri hakkında sorular sorarak, kendi kendine araştırma görevleri vererek öğrenmeyi öğrenen bireylerin özelliklerini Türkçe dersinde gösterdiklerini düşünüyorum. Araştırdiğ $\mathrm{l}$ konuyu ve yeni ögrendiği bilgiyi irdeliyor. Konu ile ilgili örnekler bulup bu örnekleri çoğaltabiliyor.” (Ö9)

"Sorulara daha farkli cevap verebiliyorlar. Olağanın dişında, beklenmedik cevaplar. Demek ki düşünüyorlar. Ayrica farklı sorular da soruyorlar. Ögrenmek istiyorlar, meraklılar, bilmek istiyorlar. Bazen ben söylemeden "ögrretmenim araştıralım mı? Anlatalım mi? " diyen birkaç öğrencim oluyor. Bazen gerek yok desem de "ben araştırmak istiyorum" diyen ögrencilerim var." (Ö7)

Öğrenmeyi öğrenen bireylerin özelliklerine ilişkin öğrencilerinin "sorgulayıcı olma, soru sorma" şeklinde davranış gösterdiğini söyleyen öğretmenlerden bazılarının görüşleri aşağıda verilmiştir.

"Yani çocuk sık sık geliyor bana soru soruyor. Yani hep merak ediyor. Hep merak ettiği için soru sormak durumunda kalıyor. Eskiden çocuklar soru sormazd, ögretmenim siz söyleyin derlerdi. Şimdiki çocuklar ögretmenim şu ne, bu ne ve bu nasil olur şeklinde sürekli araştırıcı sorular soruyor." (Ö3)

Öğrenmeyi öğrenen bireylerin özelliklerine ilişkin öğrencilerinde "yaratıcı olma" şeklinde davranış gösterdiğini belirten öğretmenlerden bazılarının görüşleri aşağıda verilmiştir.

"Kendi kelimeleriyle, düşünceleriyle bir iki kıtalı şiirler yazlyor birkaç ögrencim. Yeni bir konu, kelime ögrendiğinde kendileri cümle içerisinde kelimenin anlamına uygun olarak kullanıyorlar, cümle yazıyorlar. Eş anlaml-zit anlamlı kelimelerde yeni kelimeler buluyorlar." (Ö8)

"Akrostiş çallşması şeklinde şiir yazan, hikâye yazan ögrencilerim de var. ” (Ö7)

"Çocuklar hep kendileri üretmeye yönelik çalışmalar yapıyor. Daha sonra mesela ben bir çalışma yaptığım zaman hemen bir tanesi diyor ki ögretmenim bununla ilgili bir resim yapalım. Yani hikâyenin altına hemen resim yapmaya başlyyorlar. Yani çocuklar gerçekten ögrenmeyi ögrenmiş oluyorlar benim gözümde yani becerebiliyorlar. Kendi başlarına yapabiliyorlar.” (Ö3)

Öğrenmeyi öğrenen bireylerin özelliklerine ilişkin öğrencilerinde "farkında olma" şeklinde davranış gösterdiğini belirten öğretmenlerden bazılarının görüşleri aşağıda verilmiştir.

Başta son derse hazırlık bölümü hiç dikkatlerini çekmiyordu. Şimdi soruyorlar bunun hakkında araştırma yapacak mıyı, resim yapacak mıyız şeklinde. Artık kendileri öneri getiriyor. Fark ediyorlar şimdi. (Ö6)

Atasözleri ve deyimleri örnek verebilirim. Örneğin, yaramazlık yapan ögrencime "iğneyi kendine çuvaldızı başkasına batır" atasözünü araştırması için verdim. Bu yolla ögrencim hem araştırlyor hem de ailesine de sorarak sorgulaylcl birey olabiliyor. Sonucunda da neden bu atasözünü ona verdiğimin farkına varlyor. Bu tür etkinlikleri hem olumlu hem olumsuz davranış gösteren ögrencilerime uyguluyorum. (Ö1) 
Öğrenmeyi öğrenen bireylerin özelliklerine ilişkin öğrencilerinde "anlatma, paylaşımcı olma" şeklinde davranış gösterdiğini söyleyen öğretmenlerden bazılarının görüşleri aşağıda verilmiştir.

Öğrendikleri şeyleri bazen başkalarıla paylaştıklarını duyuyorum. Arkadaşlarına anlatırken işte kulak misafiri olduğumuz zamanlar oluyor. Bu da hani onlardaki kalıcılığı aslında kavradıklarını, yerleştirdiklerini gösteriyor. (Ö2)

\section{"Herhangi bir olayı oluş sırasına göre anlatabiliyorlar.” (Ö8)}

Araştırmaya katılan öğretmenler öğrenmeyi öğrenen bireylerin özelliklerini kalıcı öğrenme boyutunda araştırma yaparak, sorgulayarak, kendi kendine öğrenerek, konuyu neden öğreneceklerinin farkında olarak, başkalarıyla bilgilerini paylaşarak ve meraklı olarak sağlanacağını belirtmektedirler. Ayrıca öğrenmeyi öğrenen bireylerin üretkenlik noktasında yaratıcı olduklarını söylemişlerdir.

\section{Öğrenmeyi Öğrenen Bireyler Yetiştirme Temasına Yönelik Öğretmen Görüşlerine Ait Bulgular}

Araştırmaya katılan öğretmenlerin öğrenmeyi öğrenen bireyler yetiştirmelerine ilişkin görüşleri Tablo 6'da verilmiştir.

Tablo 6. Öğretmenlerin Öğrenmeyi Öğrenen Bireyler Yetiştirmelerine İlişkin Görüşleri

\begin{tabular}{lll}
\hline Öğrenmeyi öğrenen bireyler yetiştirme & $\mathrm{n}$ \\
\hline & Araştırma yapma & 7 \\
\cline { 2 - 3 } & Anlatma & 6 \\
\cline { 2 - 3 } & Kendini ifade etme, özgüven & 5 \\
\cline { 2 - 3 } & Yaratıcıllk & 3 \\
\cline { 2 - 3 } & Sorgulayııı olma & 2 \\
\cline { 2 - 3 } & Okuma & 2 \\
\cline { 2 - 3 } & Tartışma & 1 \\
\hline
\end{tabular}

Tablo 6 incelendiğinde araştırmaya katılan öğretmenlerden yedisi öğrencilerinde öğrenmeyi öğrenen bireylerin özelliklerinden olan araştırma yapma özelliğini geliştirdiğini düşünmektedir. Altı öğretmen ise araştırdıkları, öğrendikleri konuları sınıfta anlattırdığını söylemiştir. Beş öğretmen kendini ifade etme ve konuşma becerisi sayesinde öğrencilerinin iletişim ve özgüvenlerinde olumlu yönde gelişim sağladığını belirtmiştir. Üç öğretmen öğrencilerinin yaratıcılıklarını geliştirdiğini, 2 öğretmen ise sorgulayıcı bireyler olmalarına yardımcı olduğunu ifade etmiştir. Diğer 2 öğretmen de öğrencilerinde okuma alışkanlığını geliştirerek kendi kendilerine daha iyi öğrenebildiklerini, kelime dağarcıkları geliştiği için daha iyi hikâyeler yazabildiklerini düşünmektedir. Araştırmaya katılan öğretmenlerden sadece biri öğrencilerinin kendisiyle bazı konularda tartışmaya girdiğini, onların tartışma davranışını ortaya çıkardığını bildirmiştir.

Öğretmenlerin bazılarının görüşleri aşağıda verilmiştir.

Ĕ̆er öğrencim anlamını bilmediği kelimeyi hiç cümle içinde okumadan veya anlamını çıkarmaya çalışmadan gelirse ona "anlamın bilmediği kelimeyi ilk gördügünde gelmemesi gerektiğini, biraz araştırması ve düşünmesi gerektiğini” söylüyorum. (Ö1)

Okumayı daha çok seviyorlar. Okuma saati bitse bile okuyalım diyorlar. Daha kapsamlı hikâye yazmaya başladılar. Cümleleri farklılaşmaya başladı. Kendi kendine yazdıkları şiirler daha uzun ve güzel oluyor artık. Bu yıl daha çok araştırma yapmak istiyorlar. (Ö7)

Bazl etkinliklerde ailesini katabiliyor, bu etkinliklerde. Mesela, kütüphaneye gidiyorlar konulardan hangi konuysa onlar gidiyorlar kütüphaneden araştırlyorlar ya da aileleriyle fikir alışverişinde bulunuyorlar. Onları gelip sinıfta anlatıyorlar. (Ö4)

Kendini ifade etme aklıma ilk gelen özellikleri. Dediğim gibi birinci sınıf oldukları için ilk başlarda çekingen davranıyorlardı. Şimdilerde kendilerini çok iyi ifade edebiliyorlar. Özgüven duygularını geliştirdiğimi düşünüyorum. Ilk geldiklerinde çoğu ketumdu. Şimdi hem benimle hem arkadaşlarıla rahat bir şekilde iletişim kurabiliyorlar. Haberleri izleyip sınıfta anlatıyorlar. (Ö8)

Evet, bence en başta çocuklarda özgüven gelişiyor. Yani bir şeyi yapabilme konusunda ben bu işi yapabilirim. Birinci sinıfa gelen çocukta çok fazla kendini ifade edememe sıkıntısı vardır. Daha sonra çocukta başarma duygusu geliştirdiyseniz öğrenmeyi öğrettiyseniz, çocuk yapabilme duygusuyla hep daha iyisini daha yenisini yapmaya çalışır. Bu da özgüven duygusu, başarma duygusunun geliştiğini ben hissediyorum. Hatta bazı zaman benim ögrenciler benimle tartışmaya giriyor. Bilen çocuk tartı̧̧maya girer. Bilmeyen çocuk tartışamaz. Yani küçük deyip geçmemek lazım. O küçük çocuklar tartışabiliyor. Hayır, öğretmenim siz bu konuda yanlış düşünebilirsiniz diyebiliyorlar. (Ö3)

Toplumsal yönden gelişebilmek için önce bireysel gelişim göstermek gerekmektedir. Araştırmaya katılan öğretmenler öğrenmeyi öğrenen bireylerin özelliklerini belirtirken öğrencilerinde bireysel yönde bir gelişim sağladıkları anlaşılmaktadır. Çünkü birey araştırma yaptıkça, anlattıkça, kendini ifade edebildikçe, yaratıcılığını geliştirdikçe, sorguladıkça, okuyup tartıştıkça kendini geliştirebilir, bireysel anlamda gelişim gösterebilir. $\mathrm{Bu}$ açıdan bakıldığında öğretmenlerin öğrencilerinde öğrenmeyi öğrenen bireyin özelliklerini geliştirme eğiliminde olduğu söylenebilir.

Araştırma sonunda öğretmenlere öğrenmeyi öğrenme ile ilgili belirtmek istedikleri başka görüş olup olmadıkları sorulduğunda, genel anlamda olumlu bulduklarını, öğretmenlerin bu süreçte rehberlik ettiği/yol gösterici konumunda olduğunu, öğrenmelerin daha kalıcı olduğunu, öğrencinin kendisinin öğrenmesinin çok önemli olduğunu, yaşam boyu devam ettiğini, araştırma ve sorgulama duygularını harekete geçirdiğini belirtmişlerdir. Öğrenmeyi öğrenme ile ilgili 2 öğretmen bu soruda herhangi bir görüş bildirmemiştir.

\section{Sonuç, Tartışma ve Öneriler}

Nitel araştırma modellerinden durum çalışması ile desenlenen bu araştırmada 5 kadın, 4 erkek öğretmen olmak üzere toplam 9 öğretmen ile görüşmeler gerçekleştirilmiştir. Ayrıca maksimum çeşitliliği arttırmak için mesleki kıdem, okuttuğu sınıf, bu okuldaki görev süresi, eğitim durumu ve okulun bulunduğu sosyo-ekonomik düzey de dikkate alınmıştır.

MEB tarafından 2017 yılında güncellenen ve 2018-2019 eğitim öğretim yılında uygulamaya konan 2018 y1lı Türkçe dersi öğretim programında yer alan yetkinlikler 
bölümündeki "öğrenmeyi öğrenme” yetkinlik alanının sınıf öğretmenleri görüşlerine göre değerlendirilmesini amaçlayan bu araştırmada, elde edilen bulgular doğrultusunda ulaşılan sonuçlar şu şekildedir:

Araştırmaya katılan öğretmenlerin büyük bir çoğunluğu 2018 y1lı Türkçe dersi öğretim programındaki yetkinliklere olumlu baktıklarını belirtmişlerdir. Ayrıca öğretmenlerle yapılan görüşmelerde, programı yeterince incelemedikleri ve yetkinlikler konusunda yeterli bilgiye sahip olmadıkları sonucuna da ulaşılmıştır. Öğretmenlerin uygulanan programları yeterince incelemedikleri söylenebilir. Araştırma sonuçları, yapılan bazı çalışmalarla (Alver ve Sancak, 2016; Bıçak ve Alver, 2018; Susar-Kırmızı ve Yurdakal, 2019) da örtüşmektedir. Her ne kadar araştırmaya katılan öğretmenler Türkçe dersi öğretim programını incelemediğini söyleseler de "öğrenmeyi öğrenme" kavramına yükledikleri anlam doğrultusunda görüş belirtmişlerdir. Öğrenmeyi öğrenmeye ilişkin kendi kendine öğrenme en çok anlam yüklenen kavram olurken araştırma yapma en az anlam yüklenen kavram olarak araştırma sonucunda ortaya çıkmıştır. Öğrenmeyi öğrenen bireylerin özellikleri düşünüldüğünde, öğretmen görüşlerine göre, öğrenmeyi öğrenme kavramına araştırma yapma anlamı da yüklenebilirdi. Çünkü araştırmada "öğrenmeyi öğrenen bireyler yetiştirme noktasında" araştırmaya katılan öğretmenlerin en çok öğrencilerinde "araştırma yapma" özelliklerini geliştirdikleri yönünde sonuca ulaşılmıştır. Bu sonuç doğrultusunda, araştırmaya katılan öğretmenlerin öğrenmeyi öğrenme yetkinlik alanına yükledikleri anlam ile öğrenmeyi öğrenen bireyler yetiştirmelerine ilişkin görüşleri arasında zıtlık olduğu belirtilebilir.

Araştırmada, öğretmenler "öğrenmeyi öğrenme” yetkinlik alanında öğrencilerin kendi öğrenme eylemini etkili zaman ve bilgi yönetimini de kapsayacak şekilde bireysel olarak; "anlamını bilmediği kelime çalışması", "metni tahmin etme", "metne başlık önerme", "hikâye tamamlama", "özgün şiir yazma, hikâye oluşturma" gibi etkinlikler yaptıklarını belirtmişlerdir. Grupla ise "dil bilgisi çalışmaları", "hikâye oluşturma", "şiir yazma", "hikâye tamamlama”, "deyim ve atasözü çalışmaları" gibi etkinliklere daha çok yer verdiklerini belirtmişlerdir. Bundan hareketle öğretmenlerin derslerde öğrencilerin hayal gücünü geliştirici ve yaratıcılıklarını destekleyici etkinlikler yaptığı sonucuna ulaşılabilir. Bu tür etkinliklerin hem ögrrencilerin derslere olan olumlu tutumlarını arttıracağ 1 hem de öğrencilerin üst düzey düşünme becerilerinin gelişmesine yardımcı olacağı söylenebilir. Yapılan bazı araştırmalar bu sonucu desteklemektedir. Söylemez (2018) yaptığı çalışmada eleştirel, yansıtıcı, yaratıc1 düşünme ve problem çözme gibi üst düzey düşünme becerilerine yönelik 2018 Türkçe dersi öğretim programında yer alan temel dil becerilerine ait kazanımların belirlendiğini belirtmiştir. $\mathrm{Bu}$ araştırmada öğretmen görüşlerine göre öğrenciler tarafindan yapılan bireysel etkinliklerin ve grup etkinliklerinin öğrencilerin eleştirel, yansıtıcı, yaratıcı düşünme becerileri ile problem çözme becerilerini destekler nitelikte olduğu belirtilebilir. Akın, Çıray ve Sönmez (2013) çalışmalarında, öğretim sürecinde uygun öğrenme stratejisini seçen ve kullanan öğrencilerin zamanlarını etkili biçimde kullandıkları ve öğrenmeye ayırdıkları süreyi iyi yönettikleri sonucuna varmışlardır. Ayrıca zaman yönetimi konusunda iyi bir beceriye sahip olan bir öğrencinin öğrenme sürecine hâkim olacağı, uygun öğrenme stratejilerini kullanmasıyla birlikte öğrenmeyi öğrenen bir birey haline geleceğini de düşünmektedirler. Mercan (2011) öğrencilerin öğrenmeyi öğrenme düzeylerini duyuşsal ve bilişsel beceriler olmak üzere iki ana ölçüte dayalı olarak incelediği araştırmada, farklı boyutlarda öğrencilerin ortalamanın üzerinde bir puan aldıkları sonucuna ulaşmıştır. Buna göre, öğrencilerin duyuşsal beceriler ölçeğinin boyutları olan "Okul ve Birey", "Öğrenme ve Çalışma Alışkanlıkları", "Grup Çalışmasıı”, "Bireyin Karakter Eğilimi” boyutlarında olumlu eğilim içerisinde bulunduğu sonucuna ulaşılmıştır. Bilişsel beceriler ölçeğinin boyutları olan "Akıl Yürütme", "Kavram Bulma", "Aritmetik İşlemler", "Metin Kavrama", "Tarihsel Zamanlamaya", "Coğrafya", "Sanat ve Kültür", "Değişkenlerin Kontrolü” boyutlarında ise öğrencilerin her boyutta farklı düzeyde oldukları ancak toplam puanda orta noktada bulundukları sonucuna ulaşılmıştır. Öğrencilerin bireysel ve grup etkinlikleri incelendiğinde, duyuşsal beceriler ölçeğinin alt boyutları ile benzerlik gösterdiği görülmektedir. Buna göre etkinliklerin, öğrencilerin hem bilişsel hem de duyuşsal becerilerini destekler nitelikte olduğu görülmektedir. Çerçi’nin (2005) araştırmasında, "öğrenmeyi öğrenme" stratejilerinin uygulandığı deney grubuna son test olarak uygulanan başarı testi ve tutum sonuçlarına göre deney ve kontrol grubu arasında anlamlı bir fark olduğu ve bu farkın da deney grubunun lehine olduğu belirlenmiştir. Son testlerde deney grubu öğrencilerinin kontrol grubu öğrencilerine göre daha başarılı oldukları ve Türkçe dersine karşı olumlu tutum geliştirdikleri sonucuna ulaşılmıştır. Bu bulgunun, eldeki araştırma bulgusu ile örtüştüğü söylenebilir. $\mathrm{Bu}$ durum, sınıf içinde öğrencilere "öğrenmeyi öğrenme" yetkinliğini geliştirici stratejileri kullanmanın önemini destekler niteliktedir.

Öğretmenler, öğrencilerin Türkçe dersinde öğrenmeyi öğrenen bireyin özelliklerini daha çok araştırma yapma, sorgulama, yaratıcı olma, kendi kendine öğrenme, farkında olma, meraklı, anlatma ve paylaşımcı olma gibi davranışlar ile gösterdiklerini söylemişlerdir. Araştırma sonucu 2018 yılı Türkçe öğretim programının öğrencilerden beklediği üst düzey düşünme becerileriyle ve bazı araştırma sonuçlarıyla da örtüşmektedir. Güneş (2012) yaptığı çalışmada, günümüz dünyasında karmaşık sorunların üstesinden gelmek için öğrencilerin düşünme, anlama, sorgulama, sorun çözme, araştırma, değerlendirme gibi zihinsel becerilerini geliştirme ile öğrencinin okulda öğrendiklerini yeni iş ve görevlerde, karmaşık durumlarda hayat boyu kullanma kapasiteleri üzerinde önemle durulduğundan bahsetmektedir. Figel (2007), "Yaşam Boyu Öğrenmede Anahtar Yeterlikler-Avrupa Çerçevesi" çalışmasında bireylerin sadece öz disiplinle kendi kendine öğrenmeye zaman ayırmasını değil, aynı zamanda işbirliği içinde çalışarak öğrenme sürecinin bir parçası olmayı ve heterojen bir gruptan faydalanarak öğrendiklerini paylaşmaları gerektiğini belirtmektedir. Bu sayede bireyin öğrendiklerini transfer edebileceği, öğrenmenin kalıcılığının da artabileceği söylenebilir. Araştıran, sorgulayan, yaratıcı olarak yeni bilgiler ortaya koyabilen, öz denetimle kendi kendine öğrenebilen ve bu öğrendiklerini başkalarıyla paylaşabilen öğrencilerin aynı zamanda ezbere dayalı öğrenmeden uzaklaşacağı, bilgiye nasıl ulaşacağını ve yapılandıracağını öğreneceği düşünülebilir. Bilgi transferi sayesinde de bilginin 
işlevselliğinin artması, bu sayede de bireylerin, öğrenmeyi öğrenen bireylerin özelliklerini göstermesi gerçekleşebilir.

Doğan (2105), yaratıcılı̆̆ın tüm bireylerde var olabileceğini fakat bireylerin yaratıcılığında yeteneğin, zekânın, çevrenin, eğitimin vb. etkisinin doğru orantılı olarak arttırılabileceğini vurgulamaktadır. $\mathrm{Bu}$ araştırmada da öğretmenler öğrencilerinde öğrenmeyi öğrenen bireylerin özellikleri dikkate alındığında araştırma yapma, anlatma, kendini ifade etme, özgüven, yaratıcılık, sorgulayıcı olma gibi davranışları geliştirdiklerini düşünmektedirler. Çatal (2019), yaptığı araştırmada sınıf öğretmenlerinin öğrenmeyi öğrenme becerileri konusunda kendilerini oldukça yeterli olarak algıladıkları sonucuna varmıştır. Bu sonuç araştırma bulgularını desteklemektedir. Ayrıca, bu sonucun öğrencilerin Türkçe derslerinde göstermiş oldukları öğrenmeyi öğrenen bireyin özellikleriyle benzerlik gösterdiği belirtilebilir.

Yapılandırmacılık eğitim felsefesinin hâkim olduğu eğitim sistemimizde öğretmenlerin bilgiyi aktaran konumunda değil, öğrencilerine bilgiye ulaşma yollarını gösteren rehber bir konumda olması önemli görünmektedir. Öğrenciler ulaştıkları bilgileri kalıcı hale getirebilmek için kendilerine göre anlamlandırabilmeli, özgün ve yeni bilgiler üretebilmeli, aynı zamanda bu bilgileri de işlevsel olarak yaşamlarında kullanabilmelidirler. Özellikle gelişmekte olan ülkeler için bilimin çok önemli olduğu söylenebilir. Bilim üretebilmek için öncelikle bilgiyi yapılandırabilmenin, özgünlüğün ve işlevselliğin gerekliliği düşünülebilir. Bireylerde öğrenmeyi öğrenme yetkinliğinin geliştirilmesi ise bunları gerçekleştirince sağlanabilir. Bu sürecin, yaşam boyu devam etmesi de devamlılığın sağlanabilmesi ve kalıcılık açısından önemli görünmektedir. Çünkü yaşamda kullanılmayan her türlü bilgi zamanla işlevselliğini kaybedebilir. $\mathrm{Bu}$ nedenle öğrenme ve öğrenmeyi öğrenme, yaşam boyu devam eden bir süreçtir. Öğrenmeyi öğrenme kavramı işlevselliği bakımından birçok kaynakta hayat boyu öğrenme kavramının içinde ve birlikte ele alınmıştır. (Cornford, 2002; Erdamar, 2015; Figel, 2007). Araştırma sonucunda öğretmenlere öğrenmeyi öğrenme ile ilgili belirtmek istedikleri başka görüş olup olmadıkları sorulduğunda, genel anlamda olumlu bulduklarını, öğretmenlerin bu süreçte rehberlik ettiği/yol gösterici konumunda olduğunu, öğrenmelerin daha kalıcı olduğunu, öğrencinin kendisinin öğrenmesinin çok önemli olduğunu, yaşam boyu devam ettiğini, araştırma ve sorgulama duygularını harekete geçirdiğini belirtmişlerdir. Susar-Kırmızı ve Yurdakal (2019) araştırmalarında, 2018 yılı programı ile bilgi çağında gereksinim duyulan bireylerin yetiştirilip yetiştirilemeyeceğine ilişkin olarak öğretmenlerin büyük bir çoğunluğu olumsuz görüş bildirmekte ve 2018 y1lı Türkçe dersi öğretim programıyla bu hedeflenen bireylerin yetiştirilemeyeceğini düşünmektedir. Araştırmadan elde edilen, öğretmenlerin, öğrenmeyi öğrenme sürecini olumlu ve verimli buldukları, bu süreçte rehber oldukları, öğrenmenin kalıcı olduğu ve programda yer alan kazanımların da öğrencilerin araştırma sorgulama duygularını harekete geçirdiği bulgusu, Susar-Kırmızı ve Yurdakal'ın (2019) araştırma bulgularıyla çelişmektedir. İncelenen öğretim programı aynı olmasına rağmen, öğretmen görüşleri arasındaki bu çelişkinin, çalışma gruplarında yer alan öğretmenler, öğretmenlerin görev yaptıkları okulların bulundukları sosyo ekonomik düzey ve buna bağlı olarak okulların aynı olanaklara sahip olmaması ile öğrenci özellikleri gibi farklılıklardan kaynaklandığı belirtilebilir.

Araştırma sonuçlarından hareketle aşağıdaki önerilerde bulunulabilir:

$\begin{array}{llr}\text { - Hazırlanan } & \text { öğretim } & \text { programlarının } \\ \text { öğretmenler } & \text { tarafından } & \text { yeterince } \\ \text { incelenebilmesi } & \text { için sene } & \text { başındaki }\end{array}$ öğretmenler kurulu toplantılarında ya da zümre öğretmenler kurullarında okul ve ilçe yöneticilerinin de katılımlarıyla çalıştaylar düzenlenebilir.

- Öğretmenler öğrenmeyi öğrenen bireyler yetiştirmek için derslerinde öğrencilerine daha fazla yaratıcılıklarını geliştirici etkinlikler hazırlayabilir ve demokratik sınıf ortamı oluşturarak tartışmalar yaptırabilirler.

- Öğretmenler başta Türkçe dersi olmak üzere diğer derslerde de daha fazla okuma çalışması yaptırabilir. $\mathrm{Bu}$ sayede öğrencilerinin düşünme becerilerini geliştirebilir ve sorgulayıcı bireyler olarak yetişmelerinde daha etkin rol üstlenebilirler.

- Hizmetiçi eğitimlerle öğretmenlere öğrenmeyi öğrenme yetkinlik alanının günümüzdeki eğitim felsefesiyle ilişkisi ve önemi ile ilgili bilgilendirmeler yapılabilir.

- Programın uygulayıcıları olan öğretmenlerden programda yer alan diğer yetkinlik alanlarıyla ilgili görüş alınarak karşılaştırma yapılabilir.

- Öğrenmeyi öğrenme yetkinlik alanının sınıf ve diğer branş öğretmenlerinin öğretme-öğrenme ortamlarında uygulayacakları aktivitelerin etkililiği bakımından artırılması konusunda eylem araştırmaları yapılabilir.

- Yarı yapılandırılmış görüşme tekniği ile elde edilen sonuçlar, derinlemesine bilgi veren diğer araştırma teknikleriyle (odak grup görüşmesi, gözlem gibi) de yapılıp araştırma geliştirilebilir.

- Sınıf öğretmenleriyle gerçekleştirilen bu araştırma, Türkçe öğretmenleriyle ya da farklı branşlarda görev yapan öğretmenlerle de yapılabilir.

- Araştırma Burdur ilinde bulunan iki ilçede gerçekleşmiştir. Farklı illerdeki sınıf öğretmenlerinin görüşleri de alınıp araştırma sonuçları karşılaştırılabilir.

\section{Kaynakça}

Akın, Z., Çıray, F. ve Sönmez, B. (2013). Öğretmen adaylarının kullandıkları öğrenme stratejileri ile zaman yönetimi becerileri arasındaki ilişki. Ilköğretim Online, 12(3), 822-835.

Alver, M. ve Sancak, Ş. (2016). 2015 Türkçe dersi öğretim programı hakkında öğretmen/öğretmen adayı ve öğretim elemanı görüşleri. International Periodical for the Languages, Literature and History of Turkish or Turkic, 11(14), 31-60. 
Aslan, M. ve Atik, U. (2018). 2015 ve 2017 ilkokul Türkçe dersi öğretim programı kazanımlarının revize edilmiş Bloom Taksonomisine göre incelenmesi. Uluslararası Türkçe Edebiyat Kültür Eğitim Dergisi, 7(1), 528-547.

Aydın, E. (2017). Türkçe dersi öğretim programlarının (2015 ve 2017) değerlendirilmesi. Turkish Studies International Periodical for the Languages, Literature and History of Turkish or Turkic Volume, 12(28), 41-66.

Aydın, Y. ve Sadioğlu, Ö. (2018). Cumhuriyet'ten günümüze (1923-2017) ilkokul Türkçe öğretim programlarında dil bilgisi ve imla. Ana Dili Eğitimi Dergisi, 6(4), 1091-1111.

Bağc1-Ayranc1, B. ve Mutlu, H. H. (2017). 2006, 2015 ve 2017 Türkçe dersi öğretim programlarının karşılaştırılması. International Journal of Language Academy, 5(7), 119-130.

Bağcı Ayranc1, B. ve Pilav, S. (2017). Türkçe öğretim programı (2017) temaları için ege bölgesi halk edebiyatı ürünlerinin kullanılması. Sinırsız Eğitim ve Araştırma Dergisi, 2(3), 77-97.

Bıçak, N. ve Alver, M. (2018). 2018 Türkçe dersi öğretim programına ilişkin öğretmen görüşleri. Uluslararası Türkçe Edebiyat Kültür Eğitim Dergisi, 7(4), 24802501.

Cornford, I. R. (2002). Learning-to-learn strategies as a basis for effective lifelong learning. International Journal of Lifelong Education, 21(4), 357-368.

Çatal, N. (2019). Sinıf öğretmenlerinin öğrenmeyi öğrenme becerisine ilişkin görüş ve yeterlikleri. Yayınlanmamış Yüksek Lisans Tezi, Hacettepe Üniversitesi Eğitim Bilimleri Enstitüsü, Ankara.

Çerçi, A. (2005). Türkçe ögrretiminde öğrenmeyi öğrenme stratejilerinin ögrencilerin anlama düzeylerine etkisi. Yayınlanmamış Yüksek Lisans Tezi, Selçuk Üniversitesi Sosyal Bilimler Enstitüsü, Konya.

Çerçi, A. (2018). 2018 Türkçe dersi öğretim programı kazanımlarının $(5,6,7,8$. Sinıf) yenilenen Bloom Taksonomisine göre incelenmesi. Okuma Yazma Eğitimi Araştırmaları, 6(2), 70-81.

Çevik, A. ve Güneş, F. (2017). Türkçe ders kitaplarındaki etkinliklerin incelenmesi. Ana Dili Eğitimi Dergisi, 5(2), 272-286.

Direkçi, B., Akbulut, S. ve Şimşek, B. (2019). Türkçe dersi ögrretim programı (2018) ve ortaokul Türkçe ders kitaplarının dijital okuryazarlık becerileri bağlamında incelenmesi. Avrasya Uluslararası Araştırmalar Dergisi, 7(16), 797-813.

Doğan, N. (2015). Yaratıcı düşünme ve yaratıcılık. İçinde: Ö. Demirel (Ed.), Eğitimde yeni yönelimler (Geliştirilmiş 6. Baskı) (s. 167-198). Ankara: Pegem Akademi

Eken, N. T. ve Öksüz, H. İ. (2019). İlkokul (1-4) Türkçe ders kitaplarındaki hikâye edici metinlerin Türkçe dersi öğretim programındaki kök değerler bakımından incelenmesi. Ana Dili Eğitimi Dergisi, $7(2), 384-401$.

Ekmen, C. ve Bakar, E. (2018). İlköğretimde öğretim programları ve ders kitaplarında dijital yetkinliğin yeri. Milli Eğitim Dergisi, 48(221), 5-35.

Erdamar, G. (2015). Yaşam boyu öğrenme. İçinde: Ö. Demirel (Ed.), Eğitimde yeni yönelimler (Geliştirilmiş 6. Bask1) (s. 219-237). Ankara: Pegem Akademi

Erlandson, D. A., Harris, E. L., Skipper, B. L. ve Allen, S. D. (1993). Doing naturalistic inquiry: A guide to methods. California: Sage Publications.

Figel, J. (2007). Key competences for lifelong learningEuropean reference framework. Luxembourg: Office for Official Publications of the European Communities.

Glesne, C. (2015). Nitel araştırmaya giriş (5. Baskı). (Çev. Ed. A. Ersoy, P. Yalçınoğlu). Ankara: Anı Yayıncilik.

Güler, A., Halıcıoğlu, M. B. ve Taşğın, S. (2015). Sosyal bilimlerde nitel araştırma (Genişletilmiş ve Gözden Geçirilmiş 2. Baskı). Ankara: Seçkin Yayıncılık.

Güneş, F. (2017). Bologna süreci ile yükseköğretimde öngörülen beceri ve yetkinlikler. Journal of Higher Education \& Science/Yüksekögretim ve Bilim Dergisi, 2(1), 1-9.

Güneş, F. (2017). Türkçe öğretiminde etkinlik yaklaşımı. Ana Dili Ĕgitimi Dergisi, 5(1), 48-64.

Koçoğlu, A. ve Yanpar-Yelken, T. (2018). Suriyeli öğrencilere Türkçe dil becerileri kazandırma sürecinde ilkokul Türkçe dersi öğretim programları ile ilgili öğretmen görüşleri. Eğitimde Nitel Araştırmalar Dergisi, 6(2), 131-160.

Konuk, S. (2018). 2017 Türkçe dersi öğretim programında yer alan alışılmamış metin türlerini tanıyalım. Cumhuriyet Uluslararası Eğitim Dergisi, 7(4), 428452.

Maxwell, J. A. (2018). Nitel araştırma tasarımı: Etkileşimli bir yaklaşım. (Çev. Ed. M. Çevikbaş). Ankara: Nobel.

MEB (2017). Türkçe dersi öğretim programı (ilkokul ve ortaokul 1, 2, 3, 4, 5, 6, 7 ve 8. siniflar). http://mufredat.meb.gov.tr/Dosyalar/2017831428272 63-turkce.pdf. Erişim Tarihi:10.06.2019.

MEB. (2018). Türkçe dersi öğretim programı (İlkokul ve Ortaokul 1,2,3,4,5,6,7 ve 8. siniflar). Ankara: MEB.

Mercan, H. B. (2011). İlköğretim ögrrencilerinin ögrenmeyi ögrenme becerileri ve bu becerilerin akademik başarılarını yordama düzeyi. Yayınlanmamış Yüksek Lisans Tezi, Eskişehir Osmangazi Üniversitesi Eğitim Bilimleri Enstitüsü, Eskişehir.

Meydan, A. (2010). Öğrenmeyi öğrenme stratejilerinin öğrencilerin dördüncü sınıf "yaşadığımız yer" ünitesini öğrenmelerine ve kalıcılığa etkisi. Selçuk Üniversitesi Sosyal Bilimler Enstitüsü Dergisi, 23, 149-157. 
Miles, M. B. ve Huberman, A. M. (2016). Nitel veri analizi (2. Bask1). (Çev. Ed. S. Akbaba Altun, A. Ersoy). Ankara: Pegem Akademi.

Ömeroğlu, A. F. (2018). Dil bilgisi öğretiminin 2004-2017 yılları arası Türkçe dersi öğretim programları açısından incelenmesi. Ana Dili Eğitimi Dergisi, 6(1), 260-280.

Özcan, A. F. ve Yıldız, S. (2018). 2017 Türkçe dersi ilk okuma yazma öğretim programı ve uygulamaya ilişkin öğretmen görüşleri. Amasya Üniversitesi Ĕ̆itim Fakültesi Dergisi 7(2), 217-255.

Özden, Y. (2013). Eğitimde yeni değerler (9. Bask1). Ankara: Pegem Akademi.

Özenç, E. G. (2018). 2015 ile 2017 ilkokul Türkçe öğretim programının karşılaştırılmalı olarak değerlendirilmesi. Uşak Üniversitesi Ë̆itim Araştırmaları Dergisi, 4(2), 38-50.

Özer, B. (2008). Öğrencilere öğrenmeyi öğretme. A. Hakan (Ed.), Öğretmenlik meslek bilgisi alanındaki gelişmeler (ss.139-152). Eskişehir: Anadolu Üniversitesi, Açıköğretim Fakültesi yayınları.

Patton, M. Q. (2018). Nitel araştırma ve değerlendirme yöntemleri (2. Bask1). (Çev. Ed. M. Bütün, S. B. Demir). Ankara: Pegem Akademi.
Pınarcık, Ö., Danacı, M. Ö., Deniz, M. E. ve Eran, N. (2016). Okul öncesi öğretmenlerinin yaşam boyu öğrenme yeterliklerine yönelik algıları. Abant İzzet Baysal Üniversitesi Eğitim Fakültesi Dergisi, 16(4), 1966-1983.

Scott, D. (2014). Knowledge and the curriculum, The Curriculum Journal, 25(1), 14-28.

Senemoğlu, N. (2005). Gelişim öğrenme ve öğretim (12. Bask1). Ankara: Gazi Kitabevi.

Söylemez, Y. (2018). 2018 Türkçe dersi öğretim programındaki kazanımların üst düzey düşünme becerileri açısından değerlendirilmesi. Atatürk Üniversitesi Türkiyat Araştırmalarl Enstitüsü Dergisi, TAED-63 (Eylül), 345-384.

Susar-Kırmızı, F. ve Yurdakal, İ. H. (2019). Sınıf öğretmenlerinin 2018 Türkçe dersi öğretim programına ilişkin görüşleri. Ĕgitim Kuram ve Uygulama Araştırmaları Dergisi, 5(1), 64-76.

Yıldırım, A. ve Şimşek, H. (2016). Sosyal bilimlerde nitel araştırma yöntemleri (10. Baskı). Ankara: Seçkin Yayıncılik.

Yin, R. K. (2017). Durum çalışması araştırması uygulamalart. (Çev. İ. Günbayı). Ankara: Nobel Yayınlar1. 